\title{
Two Wars, Two Movements: Iraq in Light of Vietnam
}

\author{
Tom Wells
}

It started with a bang. In October 2002, five months before the Iraq War had even begun, and on two separate days, tens of thousands of people demonstrated against the likely war in cities around the United States. Well over 100,000 (perhaps twice that many) protested in Washington in what was probably the largest antiwar demonstration held there since the Vietnam War; many were first-timers. "I've never in my life done anything like this before," one 31-year-old woman told a reporter. Over 50,000 protested in San Francisco in perhaps the largest antiwar demonstration there since Vietnam too. Earlier that month more than 1.5 million protested in cities in Italy, a strong U.S. ally in Europe, including some 200,000 in Rome, almost matching the size of an antiwar demonstration in London late the previous month. Activists descended on Congress and organized a deluge of e-mails and phone calls to legislators, urging them to oppose resolutions authorizing President George Bush to wage war. When Congress overwhelmingly passed such a resolution, it sparked civil disobedience in San Francisco and other cities.[1]

There was an upsurge in student opposition to the war; dissent on college campuses was "growing exponentially," according to an organizer with the Institute for Policy Studies. Campus teach-ins and protests were "so common that prominent academics cannot meet the demand for their presence," the New York Times observed. Some activists spoke of being astounded and overwhelmed by the number of people who wanted to get involved. [2]

On January 18, 2003, despite temperatures in the mid-twenties, several hundred thousand demonstrated in Washington, surpassing the size of the October protest; at the Washington Naval Yard an "inspections team" demanded access to U.S. weapons of mass destruction. In San Francisco at least 150,000 demonstrated this time. In Pittsburgh, several thousand marched in the largest antiwar protest in that city since Vietnam; numerous small protests were held in the rural Midwest, despite particularly strong support for the war in rural America and the greater social and economic risks of speaking out there. "It was a little scary to take ourselves off-campus in this town," said a professor in Emporia, Kansas. Many who joined these demonstrations were also novices at protest. Republican business executives who had supported the Bush administration's attack on Afghanistan following the September 11, 2001, terrorist attacks published a full-page letter in the Wall Street Journal declaring that "Iraq does not pass the test." Antiwar sentiment was increasing in the labor movement. Many Christian religious leaders were also speaking out: both the National Council of Churches and the National Conference of Catholic Bishops passed resolutions opposing military action. By February 6 at least sixty-four cities had passed antiwar resolutions as well; fueled by anger at congressional complicity with the Bush administration on Iraq, that number would more than double the following month in an extraordinary grassroots movement. "It's like wildfire," one of its organizers remarked. [3]

On February 15, in an unmatched day of global protest under the slogan "The World Says No to War," over 400,000 people demonstrated in New York in freezing temperatures. Hundreds of protests were held around the world involving close to ten million people. Over a million demonstrated in London in the largest antiwar demonstration ever there; at least as many demonstrated in Rome, 250,000 in Sydney - the largest antiwar protest ever in Australia - and 200,000 in Berlin. Many organizers were stunned by the size of the protests. "We were just as surprised as everyone else," one said. "But you're seeing a new sense of confidence among organizations." The political tide appeared to be turning. The demonstrations and their political repercussions around the world "have 
radically altered the calculus of possibilities," Jonathan Schell wrote in The Nation. "Before the 15th, the war seemed unstoppable-inevitable. Now, for the first time, it is conceivable that if enough people place enough specific, concrete pressure on their governments, the war can be prevented." In a "virtual march on Washington," peace activists flooded members of Congress with phone calls and faxes. [4]

It was an unprecedented outpouring. These were the biggest antiwar demonstrations to ever take place before a war had actually begun, due in no small part to the power of the internet. "We could communicate very quickly," notes Joseph Gerson, a veteran activist with the American Friends Service Committee and one of many political veterans involved in organizing the prewar protests. The international infrastructure of the antiglobalization movement aided organization of the protests significantly. February 15 "built on a whole series of global days of action that had been organized around WTO and other trade issues going back to 1998," Leslie Kauffman, a staff organizer with the United for Peace and Justice coalition, remembers. The demonstrators included a broad spectrum of people: ordinary citizens with their families, religious activists, antiglobalization protesters, members of traditional peace groups, seniors, businesspeople, environmentalists, civil rights and feminist activists, union members, college students, and teenagers. And the movement was genuinely international. "We have created the largest, most broadly based peace movement in history," David Cortright, a cofounder of the antiwar coalition Win Without War, wrote. [5] In antiwar circles, enthusiasm and hope were soaring.

Protest against the Vietnam War had taken a far different path. Before that war had begun in earnest in the spring of 1965, protests against it had been small and politically isolated, although over 20,000 U.S. "advisers" were in Vietnam by the end of 1964, over 400 Americans had already died by then, and the United States was undertaking an extensive program of clandestine military attacks against North Vietnam and other military operations. But Americans were not facing a well-publicized and dramatic prospect of an all-out, imminent military assault at that time- the advantages of all-out assaults became more apparent in Washington after Vietnam — and the anticommunist rationale for intervening in Vietnam still resonated widely in the country. Fewer questioned their government's case for war strongly enough to protest it. With Iraq, more citizens deemed war completely unnecessary. Of course, the memory of Vietnam and government lying about it fed participation in the Iraq protests.

The contrast in numbers is stark. The first national demonstration against the Vietnam War, held in April 1965 in Washington after the sustained U.S. bombing of North Vietnam (dubbed Operation Rolling Thunder) had begun, totaled only 20,000 people, mainly students. The first national coordinating committee to end the Vietnam War, shaky and transitory as it was, was not formed until five or six months after Operation Rolling Thunder had begun and when nearly 100,000 U.S. troops were already in Vietnam (and 175,000 in all were ticketed for there); yet several national coalitions and other national antiwar organizations were on the move before the Iraq War had even started. During Vietnam, it took two more years — when U.S. troop levels had reached well over 400,000 amid gradually intensified U.S. bombing, and around 10,000 Americans had died there-before a peace demonstration attracted several hundred thousand people. And it was not until two and a half years after that, in the fall of 1969_after U.S. troop levels had peaked at about 549,000 — that over 500,000 people would turn out for a demonstration in the United States. [6]

The contrast in social composition is also marked. Mainstream religious organizations joined the antiwar movement much sooner during Iraq than they did during Vietnam (at least in terms of public statements). Pope John Paul II was an early and consistent critic of U.S. policy. Segments of organized labor, which was hawkish for years during Vietnam—some unionists even attacked protesters—and which largely supported the U.S. war in Afghanistan, also joined the antiwar movement sooner during Iraq than during Vietnam. So did military families, war veterans, and civil rights groups like the NAACP. There was also more criticism of U.S. policy in the media over Iraq (though it was accompanied by the standard cheerleading when the war began). And while student protest was central to dissent on Vietnam, students have played a secondary role on Iraq, despite joining that movement in large numbers, especially before the war began_-greater than in any other recent movement_and largely without the generational self-definitions of the 1960s. A counterculture "is much more difficult to find now," Bill Dobbs, a United for Peace and Justice activist, says. [7]

In early March 2003, more than 400 colleges and high schools in the United States participated in national, though mainly small, protests against the Iraq War, including school walkouts. It was one of the largest student actions in years. "People felt really empowered," Jessie Marshall, an organizer with the National Youth and Student Peace Coalition, recalls. Three days later, thousands of women with pink accessories ("Bush says Code Red, we say Code Pink," they chanted, mocking the government's color-coded terror-alert system) marched in Washington. A 
week later, in "a prelude of civil disobedience to come," as a reporter for the Washington Post wrote, protesters in San Francisco engaged in civil disobedience aimed at shutting down the Pacific Stock Exchange; arrestees included 60-year-old Warren Langley, a recent former president of the Exchange who had joined his first antiwar protest in January and then marched again in February. "This war seems very wrong for the entire world," Langley commented. On March 15 some 50,000 demonstrated in Washington. The next day a wave of candlelight vigils across the globe involved about a million participants. [8]

Protests erupted around the world after the U.S. bombing of Iraq commenced in full force on March 19. Some 200,000 turned out in Athens, Greece. Protesters engaged in civil disobedience in numerous cities, including New York, where they staged a "die-in" on Fifth Avenue; over 2,000 were arrested in San Francisco. On March 22, more than 300,000 marched in another huge demonstration in New York.[9]

Antiwar protest continued worldwide in the months ahead-marches, rallies, civil disobedience, vigils, teach-ins, congressional lobbying, student strikes, antiwar ads, you name it. Meanwhile the peace movement was doing a lot of strategizing. Unlike during the Gulf War in 1991, when "once the missiles started flying the movement essentially evaporated," Joseph Gerson observes, "this time the movement stuck." But the prewar eruption was the zenith of the movement (at least as of 2005), which lost momentum. "Since the war started we've had a pretty lackluster response from the grass roots," David Cortright acknowledged. "Our movement is going to get smaller before it gets bigger," conceded Bob Edgar, another Win Without War co-chairman. The immediate crisis—trying to prevent a massive deadly assault - was over, and it appeared likely to many activists and other Americans that the war would soon be over too. After all, many voices in the media were predicting a U.S. cakewalk. "It could last six days, six weeks. I doubt six months," U.S. Secretary of Defense Donald Rumsfeld had predicted the month before the U.S. attack began. The fall of Baghdad the second week of April was the end to many people. The war was over, the New York Times, the Associated Press, and other members of the media declared. (To some extent the history of the Iraq War is a history of purported turning points: the fall of Baghdad, Bush's “mission accomplished” claim, Hussein's capture, the formal transfer of sovereignty, the assault on Fallujah, the elections, and so on.)[10]

Many protesters were feeling disoriented. Why are you still out there? some were asked. Although 15,000 demonstrated in Oakland, California, on April 5, a march in San Francisco under rain on April 12 drew only several thousand people; other demonstrations worldwide that day also attracted reduced numbers. Maybe 30,000 protested in Washington, 25,000 in London. Win Without War debated whether to continue and, if so, whether to pursue a broader agenda (it decided to soldier on). United for Peace and Justice, the nation's largest antiwar coalition, considered focusing more on smaller regional events than on huge national ones. "We're not 100 percent sure how to navigate this," Leslie Cagan, cochairwoman of that group, said. “...This is very much a period of figuring out our next steps." A sense that the war would end sooner rather than later would hamper the movement for weeks.[11]

Many protesters were discouraged that they hadn't prevented the war, unprecedented as that would have been, and that Bush had apparently ignored them. "They're not listening, and it's getting harder to stay optimistic," said a United for Peace and Justice coordinator. "It was a real hit to people," young and old alike, Jessie Marshall recalls. Demoralization was widespread. There was "a tremendous letdown," David Cortright remembers. "In the first few weeks it looked like Bush was having his way." They'd mounted the largest day of antiwar protest ever on February 15, to no avail. Massive demonstrations hadn't had the effect that many people had hoped they would. Perceptions of political weakness, even impotence, would plague the movement for some time, as they did the anti-Vietnam War movement. Lack of media coverage of antiwar events (which led some groups to purchase television and newspaper ads, and which too would remain a source of frustration later) and slanted coverage were also dispiriting. Overwhelming public support for Bush-his approval rating after the fall of Baghdad was 73 percent, and about 70 percent supported the war when it began—was deflating too. Morale in the movement was slipping. And many organizers were exhausted. They'd put together mobilizations at an extraordinarily rapid pace. They needed a breather. Some people had simply tired of demonstrating. "People have been in the street for seven months," a French antiwar leader pointed out. [12]

Many activists turned their attention to related issues: publicizing false U.S. claims about Iraq's weapons capabilities before the war and pushing for an independent investigation of them; organizing to prevent other U.S. interventions overseas and to shape a new U.S. foreign policy; opposing the continued U.S. occupation of Iraq and promoting the reconstruction of the country; unseating Bush in 2004; publicizing the bloated U.S. military budget and its cost in domestic programs; fighting the erosion of civil liberties; and working for global economic justice (appropriately enough since many antiwar protesters came out of the antiglobalization movement). [13] MoveOn. 
org, that huge online network of activists, would ultimately move on to focus on domestic issues like social security and Supreme Court nominees.

Meanwhile, however, United for Peace and Justice was growing enormously. Countless local antiwar groups sought it out, wanting to be part of something bigger. More groups joined the coalition between the start of the war and that summer than did during the prewar period. And there was "lots of unglamorous, less newsworthy movement building taking place,” Leslie Kauffman recalls. [14]

Soon a guerrilla movement made its presence known in Iraq, one that exhibited a surprising level of organization and sophistication and whose attacks on U.S. forces and boldness increased almost daily. And then came the inevitable comparisons to Vietnam. "Iraq could be even worse," a Newsweek article argued in July 2003. In Iraq, "the United States has to do just about everything, but it looks as if it didn't prepare for anything." Among other blunders, the White House failed to foresee the strength, size, and sophistication of the resistance in Iraq, and badly misjudged the response it would get there. "This is way beyond the scope of anything anybody who was talking about [an upsurge in violence] expected," said a retired Defense Intelligence Agency officer the following April. Bush himself had confidently told Pat Robertson before the war began, "We're not going to have any casualties," and Deputy Defense Secretary Paul Wolfowitz had told a congressional committee, "I am reasonably certain that they will greet us as liberators." The original war plan had thus forecast a series of quick U.S. troop reductions in 2003, perhaps down to 50,000 by the end of the year. The administration's intelligence failure was gargantuan. Even many hawks and military officers began forecasting failure in Iraq without a major change in policy. The Bush administration and the military were forced to junk plans for months of relatively peaceful occupation and prepare for the possibility of years of conflict. [15]

By September 2003, only 50 percent of Americans believed the situation in Iraq was worth going to war over. And whereas 41 percent had felt that "for all intents and purposes" the war was over shortly after Bush declared an end to "major combat" on May 1, now only 10 percent did. There was "a gnawing unease about the course of this mission and a realization that the conflict will be deadlier, more expensive and longer-lasting than Mr. Bush signaled" on May 1, the New York Times noted. Bush's request for another $\$ 87$ billion from Congress to finance the war fed that unease. In early November, for the first time, a slim majority of Americans disapproved of Bush's actions in Iraq. Though opinion on the war would rise and fall with events, the public was turning against the conflict quicker than it did during Vietnam. Not until over two years into that war did a slim majority disapprove of President Lyndon Johnson's policies in Vietnam. [16]

Of course, the scales of the two wars were different, and that helps explain the drop in protest over Iraq after the crisis had passed. That September there were around 130,000 U.S. troops in Iraq, around the same number as were in Vietnam when the anti-Vietnam War movement was still getting off the ground in 1965. Around 300 Americans had died in Iraq, which was comparable to 1964 - before the antiwar movement even really got going-during Vietnam. And while more than 10,000 Iraqi civilians would be dead by February 2004, over two million Vietnamese eventually died in Vietnam. [17] In other words, after the initial "shock and awe" (to use that repulsive term) in Iraq, the size of the war there resembled the early going in Vietnam.

In late September, some 25,000 demonstrated in London. A month later, perhaps 100,000 turned out in Washington, 20,000 in San Francisco. Up to 200,000 protested in London during a visit by Bush in November. The movement was still alive; organizers spoke of a revival and increased cooperation between antiwar coalitions. An untold number of smaller protests continued around the United States; some forty weekly peace vigils were still being held in the Los Angeles area alone, despite a decline since around April. Opposition among military families and veterans was increasing, if still largely beneath the surface. "Bush lies and who dies? My son, Jesus Suarez del Solar Navarro," Jesus's father would say during a March 2004 protest organized by Military Families Speak Out and Veterans for Peace. As it did during Vietnam, the FBI undertook a systematic nationwide effort to collect intelligence on protesters. [18]

On March 20, 2004, the first anniversary of the U.S. attack on Iraq, over 300 protests were held in the United States and some 400 elsewhere around the world. At least a million turned out in Rome. The numbers were much lower in other places, however, and (as one might expect) far lower than the turnouts after the start of the war. Somewhere between 50,000 and 100,000 demonstrated in New York. In London around 25,000 protested; in Athens only around 10,000 did, and several thousand demonstrated in Sydney. [19]

The antiwar movement during Vietnam had also ebbed and flowed. Measured by turnouts at national demonstrations, which of course are merely one barometer of an antiwar movement's size and health (albeit the 
easiest to get a handle on-it's much harder to tabulate the myriad of smaller and less prominent expressions of opposition including local organizing), it did not simply grow in a linear fashion as is often remembered. After the first national demonstration in April 1965, some 25,000 protested in New York that fall, slightly more in Washington. In March 1966, about 50,000 demonstrated in New York, but attendance at protests in many other cities that day was disappointing. Eight months later, locally determined protests around the country also disappointed organizers, and only 15,000 marched in New York (when over 300,000 U.S. troops were in Vietnam). Then came the extraordinarily successful mobilizations of over 300,000 in New York and 60,000 in San Francisco in April 1967. But in the famous "confrontation" at the Pentagon that October, the numbers dropped to around 100,000 at a preconfrontation rally and to 35,000 at the Pentagon itself (where 683 people were arrested). [20]

Following a successful, national student strike and a 150,000-strong demonstration in New York the next spring, protests at the Democratic convention in Chicago in late August of 1968 drew only about 10,000 people. The movement then went into a protracted slump; the turnout for a counterinaugural protest in January 1969 in Washington was low, and the national antiwar coalition fell ill and suspended activity. But that April some 100,000 marched in a GI-Civilian demonstration in New York. Then came the massive Moratorium of October 1969, when over two million Americans expressed their opposition to the war. The Moratorium was followed by a gigantic demonstration of over 500,000 in Washington and one of 150,000 in San Francisco the next month. But then the national antiwar coalition again found itself on the brink of death and the movement suffered another slump. The U.S. invasion of Cambodia and the Kent State shootings of student demonstrators by National Guardsmen in the spring of 1970 revived the movement, however, inciting the greatest outpouring of campus dissent in U.S. history and other protests in cities all over the country, including a demonstration in Washington of over 100,000 organized in only a week's time by a horribly divided coalition. Then came yet another slump and a fracturing of the antiwar coalition (the two largest antiwar student groups - the Student Mobilization Committee and Students for a Democratic Society - had already self-destructed). The sectarianism in the movement was by then quite stark. Protests that fall were small and campuses were relatively quiet. A new coalition was formed, only to be disbanded in early 1971 and replaced by another coalition.

But in the spring of 1971 the movement rebounded with a well-publicized offensive that included protests by Vietnam Veterans against the War in Washington, a demonstration of 500,000 there and one of 200,000 in San Francisco, and massive May Day civil disobedience in Washington. Protests that fall were mainly small, however, and with U.S. ground involvement in Vietnam continuing to wind down the peace movement did too, though it mounted escalations in response to intensified U.S. bombing and waged a focused congressional lobbying campaign.

Meanwhile the moods and energies of antiwar activists had also gone up and down, and local organizing had suffered its own ebbs and flows. It was never easy, and feelings of great frustration, distress, and even hopelessness were common.

In 2004 United for Peace and Justice continued to grow, comprising over 800 groups by June. The antiwar movement "has not died away at all," Leslie Cagan told a reporter, who wrote of new recruits, including war veterans and military families, and "an increasingly energized peace movement." With no "weapons of mass destruction" found in Iraq and over 600 Americans dead by April, numerous military wives were asking, Why did we go into Iraq? "The war has been based on lies from the start," said one Iraq veteran who protested outside the Texas state capitol. The mother of a soldier killed in Iraq protested the government's ban on photographing returning coffins on military bases by inviting the media to take pictures of her son's coffin as it arrived at the Sacramento, California, airport and encouraging them to publish and distribute the images. Many opponents of the war were engaged in less visible antiwar activities than joining large demonstrations, and in less predictable places than Washington, New York, or San Francisco. The movement's reach was growing. Meanwhile public support for the war continued to erode: In June, for the first time, a majority of Americans (54 percent) said the United States had made a mistake in sending troops to Iraq. (By contrast, not until August 1968 - over three years into the major fighting in Vietnam-did a majority of Americans say it had been a mistake to send U.S. troops there.) [21]

As it did in Vietnam, disillusionment was growing among U.S. soldiers in Iraq, which was becoming by far the deadliest U.S. intervention since Vietnam for American troops. "I'm tired of every time we go out the gate, someone tries to kill me," one sergeant complained in July. Said another, "A lot of times, I look at this place and wonder what have we really done.... When we first got here, we all wanted to change it and make it better, but now I don't give a shit. What the hell am I here for?” [22]

In late August, protesters descended on the Republican National Convention in New York amid tight security 
in sweltering heat. The day before the convention opened, up to 500,000 marched against the war. It was the largest protest ever at a U.S. political convention, tremendously heartening for the movement, and an enormous success by any measure. Compare it to the paltry turnout for the 1968 Democratic convention protests in Chicago, where many peace activists feared violence and tainted Democratic hopefuls (among other things), and the similarly low turnout at the Republican national convention in 1972. The march in New York was "a very mainstream, family-oriented event," one marcher said. Many youth also participated. Civil disobedience during the convention resulted in over 1,800 arrests. [23]

The huge convention demonstration was one of the first public appearances of Iraq Veterans against the War, which had been formed weeks earlier. Though there were only about forty people in the group at the time, it found itself in the media spotlight. Vietnam Veterans against the War (VVAW), on the other hand, was not formed until over two years into the Vietnam War and did not take the national stage until four years after that with the spring 1971 protests. Another antiwar veterans group, Veterans against the Iraq War, had been formed before the Iraq War had even started. The Vietnam experience provided impetus. Veterans against the Iraq War included several leaders of VVAW, and Iraq Veterans against the War considered VVAW their model. [24]

That fall many peace activists, including younger ones, organized to defeat Bush in the presidential election, taking considerable energy from the movement. But antiwar activities continued. Some 500 national-security specialists signed an open letter stating that Iraq had been the most misguided policy since Vietnam. "We're advising the administration, which is already in a deep hole, to stop digging," one signatory remarked. In October perhaps 50,000 demonstrated in London. In Washington protesters set up more than 1,100 flag-draped mock coffins in front of the Lincoln Memorial to symbolize the number of Americans killed in Iraq. A platoon of army reservists in Iraq defied orders to deliver fuel because their vehicles were judged unsafe and because they lacked military supportmirroring other instances of U.S. troops being sent on missions without adequate equipment. Iraq Veterans against the War went on speaking tours as more soldiers sought conscientious objector status or even asylum in Canada; some pursued more creative escapes from the war, such as by failing drug or medical tests or injuring themselves. "One by one, a trickle of soldiers and marines—some just back from duty in Iraq, others facing a trip there soonare seeking ways out," the New York Times observed the following March. Many war veterans were resisting the "backdoor draft" of extended tours of duty. Spurred by the horrific U.S. destruction of Fallujah, activists (including parents of dead U.S. soldiers) delivered humanitarian aid to refugees in Iraq. [25]

In the winter of 2005, following a lull after Bush's reelection, many peace activists worked to broaden their base and build new alliances. National demonstrations marking important benchmarks would continue, they decided, but grassroots organizing would take priority. Some groups were planning lobbying campaigns to pressure Congress to stop funding the war and bring U.S. troops home. Others were building bridges to new allies by highlighting the war's costs in domestic programs and organizing state campaigns to stop the use of the National Guard in Iraq. There was also talk of increasing nonviolent resistance to the war (talk of resistance picked up at about the two-year mark of the Vietnam War too). At President Bush's inauguration in Washington on January 20, over 10,000 demonstrators gathered in the cold. "Protesters often seemed more prevalent than Bush supporters," the Los Angeles Times noted. "They appeared to have achieved their goal of making their presence known both to the president...and to the American public." Protesters also joined numerous other antiwar actions around the country that day. Cindy Sheehan, the mother of a U.S. soldier killed in Iraq and a co-founder of Gold Star Families for Peace, comprised of family members of slain U.S. soldiers, and other parents were then giving heart-wrenching talks around the nation; Sheehan had also appeared on a number of national television shows, including Good Morning America. By now only 39 percent of Americans felt the situation in Iraq was worth going to war over. Comparisons to Vietnam were "bubbling to the top" of mainstream political discussion, the New York Times pointed out. Major similarities in the two wars were political: the difficulties of creating a popular, legitimate government and effective armed forces in both Iraq and Vietnam, and of sustaining domestic support for the wars in the United States. [26]

On the weekend of March 19-20, the second anniversary of the start of the war, protests were held in over 750 cities and towns in all fifty states in the United States. They were mainly small, and attendance was uneven, but organizers had emphasized local action over large demonstrations in major cities, and their geographical breadth and number were nothing to sneeze at: more than twice as many protests took place than on the one-year anniversary of the start of the war. The movement's reach was continuing to expand, including in conservative areas. In many communities, the protests were larger than the year before. The weekend was "extraordinarily encouraging," Leslie Kauffman of United for Peace and Justice remembers. "It shows a maturity and sophistication in the movement, that 
people are really putting down roots and doing local organizing, reaching out to people who don't agree with them, talking to their neighbors, really building a movement at the grass roots, and digging in for the long haul, rather than just mobilizing people who agree with you for big splashy demonstrations." Such organizing "is what is really needed to build the kind of political power we need to end the war," she says. Typically, media downplayed the protests: they were "nowhere near as big" as the prewar demonstrations, the New York Times said. But who would have reasonably expected them to be? Still, less than 15,000 protested in New York, far fewer than a year earlier. "I think Bush's reelection took the steam out of the antiwar movement," one activist commented. [27]

Outside Fort Bragg in North Carolina, however, several thousand, including veterans of assorted stripes and members of soldiers' families, assembled for the largest demonstration there since the Vietnam War. It reflected a new peace movement strategy: to raise the public profile of antiwar veterans and members of military families, to encourage dissent within their ranks, and to zero in on the military's recruitment problems. “There's a consensus nationally that one of the biggest vulnerabilities of the Bush administration is a matter of troops, and that organizing work by military families and veterans and counter-recruitment are strategically key to derailing this war," Kauffman says. Iraq Veterans against the War now had nearly 200 members and Military Families Speak Out ten times that many. Over 1,500 U.S. soldiers had by now died in the war, which 70 percent of Americans felt was an unacceptable price. The weekend also saw the formal launching of Clergy and Laity Concerned about Iraq, which echoed the earlier Vietnam-era group Clergy and Laity Concerned about Vietnam. In London, at least 50,000 demonstrated in the weekend's largest protest. [28]

On March 24, the 40th anniversary of the first teach-in against the Vietnam War at the University of Michigan, teach-ins on the Iraq War were held in Washington, D.C, Ann Arbor, and the San Francisco Bay Area. The Ann Arbor teach-in on Vietnam had inspired a wave of teach-ins on college campuses, and organizers were now hoping to build a similar educational campaign. [29]

Meanwhile young people's involvement in the movement, which had tended to rise and fall in waves like much of the rest of the movement, had been growing, if slowly and not always sustained. They'd learned more about the war's realities; it was apparent it wasn't going away; Bush's agenda seemed to threaten their futures; older antiwar leaders were encouraging their participation; and there was increasing concern about a draft. At the well-attended second national assembly of the United for Peace and Justice coalition in February, up to a fifth of the participants were under twenty-five (and 17 percent of the coalition's new steering committee were youth), which marked a change from the group's first national assembly. "A new wave of young people is beginning to assert leadership," Joseph Gerson says. Many youth, including high school students, were participating in the expanding movement against military recruitment. Some were doing educational work on the costs and realities of the war for youth in both the United States and Iraq. Many were steeling themselves for a longer haul with an awareness that "you can't end the war with one demonstration," the student organizer Jessie Marshall says. Meanwhile other activists, mainly older ones, were in the early stages of what could be a long and hard battle to cut off the war's funding (nobody in the Senate has yet been willing to propose an amendment that talks about U.S. withdrawal, and the Democratic Party for the most part doesn't want to discuss it). Another campaign to highlight the war's human cost and raise funds for reconstruction in Iraq was also being waged, and plans were forming for another mass protest in September. [30]

As of this writing in early April of 2005, the antiwar movement was alive and growing, if struggling over ways to best nurture and surface antiwar sentiment among the public, still recovering from Bush's reelection, frustrated by media slights, and suffering predictable political disagreements (most recently over when and how the United States should withdraw from Iraq, though the movement's divisions in general are not nearly as destructive as those that destroyed antiwar organizations during the 1960s). It was also wrestling as usual with the questions of what to do next and how to exert maximum pressure on Washington. But it had built a broader base than the anti-Vietnam War movement did two years into that war, even though the size of the war in Iraq was lower in U.S. troop deployments, U.S. bombing, and both U.S. and "enemy" deaths (though one study by Johns Hopkins public health researchers released the previous fall found conservatively that the war had already cost the lives of 100,000 Iraqis, mainly due to violence). [31] It would be unrealistic to expect several hundred thousand people to attend national demonstrations every year. Movements fluctuate, they gain and lose momentum, they fight uphill battles, divisions are virtually always a problem, and people drop in and out of them. But it is likely that this one will continue to show its staying power, as did the movement against the Vietnam War, and in ways that will not always be recorded in one's morning newspaper.

Still, the differences in student involvement in the Iraq and Vietnam antiwar movements remain significant. Certainly, the current absence of a draft_-"that potent fuel for an antiwar movement," as Alexander Cockburn has 
written - is a major reason. War becomes far more immediate, personally relevant, and threatening for youths who face the prospect of fighting in it; a draft can also affect their parents. While U.S. officials might exaggerate the role that self-interest plays in fanning antiwar activity (they certainly did during Vietnam, and some of their theories were pretty wacky), it's not inconsequential. Many students during the Vietnam War worried about losing their student deferments and receiving a one-way plane ticket to Vietnam. Hence, President Lyndon Johnson rejected advice to abolish student deferments, a step he felt would further inflame students, and the Nixon administration eventually went to a draft lottery that limited liability to one year. "This will take care of a lot of the draft dodgers," Nixon remarked. And consider all the forms of protest over the Vietnam draft that are absent from today's antiwar movement: the formation of "We Won't Go" groups on college campuses and of the Resistance national antidraft organization; protests against class ranking by the Selective Service System; actions ranging from leafletting to sit-ins to mobile civil disobedience at draft boards and draft induction centers; outright resistance to the draft in the forms of public noncooperation, draft card burnings, and induction refusals; draft counseling; the destruction of draft records; the flooding of the system with applications for conscientious objector status; public adult support for draft resistance - the list could go on. Draft protest was a conspicuous part of that movement. [32]

Which is one reason the Bush administration is so reluctant to reinstitute the draft, despite the army's and marines' recruitment problems. But, attune to the possibility, some peace activists launched a campaign under the slogan "No draft, no way" that included plans for blockades of military recruitment offices and student walkouts. It's not easy to organize around fear of a draft without the real thing, however.

Of course, during the 1960s many students had been involved in civil rights, campus, antibomb, and other protests before the Vietnam War took off, which fostered participation in the antiwar movement. To an extent, the movement against the Vietnam War grew out of the civil rights movement and the early New Left. Students today have had less previous experience with protest, the antiglobalization movement aside. And there are other roots of student activism in the 1960s that are not operative today, such as the baby boom, the long post-World War II economic boom (students now face a tougher job market), the growth of universities, the oppositional subcultures of the 1950s, and so on.

What has the movement against the Iraq War accomplished? The fall 2002 protests in the United States and overseas probably fed into the Bush administration's decision to seek congressional and United Nations support for war, which delayed the attack on Iraq (small consolation as that might be to people enraged and depressed when the war began). "If they were going to launch it, they had to at least go through the motions of consulting with the United Nations," Joseph Gerson argues. Opposition overseas was also probably a factor in the administration's failure to secure a UN Security Council resolution authorizing war, which undermined the credibility of U.S. policy, and in the weakness and eventual unraveling of Bush's war coalition. The movement may have also influenced administration efforts to limit casualties on both sides, grossly insufficient as those efforts have been; the Vietnam experience played a larger role in U.S. war planning. Primarily for domestic political reasons, the Bush administration has been determined to limit the number of U.S. troops in Iraq. The movement has surely exerted some effect on public opinion on the war, unquantifiable as that effect is, although the war's doubtful prospects, its mounting cost in American lives, and majority Iraqi opposition to the U.S. presence have probably had greater influence. Without the massive prewar protests, that 70 percent that supported the war when it began would probably have been even greater. The demonstrations "opened the national debate up in quite a profound way," Gerson maintains, and "laid the groundwork for the war becoming the issue it was in the last election." "Obviously the war has gone so badly that it was doomed to not be hugely popular," Leslie Kauffman asserts. "But given what we've been up against in terms of a very powerful propaganda machine, we've been enormously effective in consistently increasing the unpopularity of the war." 'The movement's generally mainstream tenor helped (I'm not aware of any polls showing the degree of public dislike of protesters that was evident during Vietnam). The movement may have also emboldened some members of Congress to speak out, including in calls in the House for U.S. withdrawal. [33]

As the fighting continues in Iraq, it seems likely that broad opposition in the United States combined with perceptions in Washington that Iraq's a loser will eventually force the administration to depart (while of course claiming success). And then, as Lawrence Freedman has observed, when other U.S. interventions are weighed in the future, people will seek assurances that they will not be "another Iraq," and officials will worry about how to overcome "the Iraq syndrome." [34] 


\section{Endnotes}

1. Washington Post, October 14, 21, 27, 2002; New York Times, October 30, 2002; San Francisco Chronicle, October 27, 2002. The vast majority of newspaper articles cited in these notes are available in the archives on the Common Dreams website at http://www. commondreams.org/archives.htm.

2. Washington Post, October 14, 2002; New York Times, October 12, 2002.

3. San Francisco Chronicle, January 19, 21, 2003; New York Times, January 15, April 5, 2003; Pittsburgh PostGazette, January 26, 2003; Christian Science Monitor, January 28, 2003; "Antiwar America," The Nation, March 31, 2003; Reuters article, February 6, 2003; John Nichols, "Building Cities for Peace," The Nation, March 31, 2003.

4. New York Times, February 15, 2003; Agence France Presse article, February 16, 2003; Daily Telegraph, February 15, 2003; Washington Post, March 3, 2003; Jonathan Schell, “The Will of the World," The Nation, March 10, 2003; Reuters article, February 26, 2003.

5. Joseph Gerson interview; Bill Dobbs interview; Leslie Kauffman interview; David Cortright, "What We Do Now: A Peace Agenda," The Nation, April 21, 2003.

6. See Tom Wells, The War Within: America's Battle over Vietnam (University of California Press, 1994; Henry Holt, 1996; iUniverse, 2005) on events of the anti-Vietnam War movement, and Herbert Schandler, The Unmaking of a President: Lyndon Johnson and Vietnam (Princeton University Press, 1977), p. 352, on U.S. troop levels in Vietnam. I examined assorted Vietnam War websites to determine U.S. deaths in Vietnam at stages of the war.

7. Dobbs interview.

8. Jessie Marshall interview; Washington Post, March 6, 9, 15, 2003; San Francisco Chronicle, March 14, 2003; Andrew Boyd, "The Web Rewires the Movement," The Nation, August 4/11, 2003.

9. Agence France Presse articles, March 20, 23, 2003; San Francisco Chronicle, March 20, 25, 2003; AP article, March 27, 2003; www.unitedforpeace.org.

10. Jonathan Schell, "Thinking Movement, Working Demonstration," The Nation, June 23, 2003; Gerson interview; Washington Post, July 22, 2003; Liza Featherstone, "The Road to Peace," The Nation, April 14, 2003; Globe \& Mail, February 8, 2003; Richard Becker interview; New York Times, April 20, 2003.

11. Gerson interview; Washington Post, April 13, 2003; AP articles, April 11, May 27, 2003; Cortright interview; San Francisco Chronicle, April 6, 13, 2003; New York Times, April 20, 2003.
12. Reuters article, February 6, 2003; San Francisco Chronicle, March 20, 2003; AP article, May 27, 2003; Marshall interview; Cortright interview; Kauffman interview; Los Angeles Times, February 4, 2003; New York Times, April 20, 2003; Washington Post, April 13, 2003.

13. New York Times, April 20, 2003; Christian Science Monitor, April 15, 2003; AP article, May 27, 2003; Boston Globe, June 20, 2003.

14. Kauffman interview.

15. Newsweek, July 25, 2003; Christian Science Monitor, April 8, 2004; CNN news release, October 20, 2004; Washington Post, December 2, 2004; New York Times, May 16, 2004; San Francisco Chronicle, May 9 , 2004.

16. Gallup News Service article, September 23, 2003; New York Times, September 15, 2003; Independent, November 3, 2003; Reuters article, April 2, 2004; Philip E. Converse and Howard Schuman, "'Silent Majorities' and the Vietnam War," Scientific American, June 1970, p. 23.

17. Knight-Ridder article, September 18, 2003; Reuters article, November 14, 2003; Independent, February 8, 2004.

18. AP article, September 28, 2003; Newsday, October 26, 2003; Washington Post, October 26, 2003; Reuters article, November 20, 2003; Los Angeles Times, November 10, 2003; Karen Houppert, "Against the War But Married To It," The Nation, November 10, 2003; Agence France Presse article, March 15, 2004; New York Times, November 23, 2003.

19. www.unitedforpeace.org; Reuters article, March 20, 2004; New York Times, March 21, 2004; Inter Press Service article, March 21, 2004.

20. See Wells, The War Within, on the anti-Vietnam War movement.

21. Philadelphia Inquirer, June 1, 2004; New York Times, April 11, 2004; Fort Worth Star-Telegram, July 7, 2004; Los Angeles Times, June 28, 2004; CNN news release, June 24, 2004; Hazel Erskine, "The Polls: Is War a Mistake?” Public Opinion Quarterly, spring 1970, p. 141.

22. Inter Press Service article, June 24, 2004; KnightRidder articles, April 17, July 21, 2004.

23. Boston Globe, August 30, 2004; USA Today, September 3, 2004; Wells, The War Within, pp. 276280 and 552; Oregonian, August 30, 2004; Marshall interview; AP article, September 4, 2004. 
24. Boston Globe, September 2, 2004; Wells, The War Within, pp. 139-141 and 492-496.

25. OneWorld.net, October 13, December 28, 2004; Agence France Presse article, October 17, 2004; AP article, October 24, 2004; Clarion-Ledger (Mississippi), October 15, 2004; Inter Press Service articles, October 26, December 3, 2004; New York Times, March 18, 2005; Los Angeles Times, December 27, 2004.

26. Marshall interview; www.unitedforpeace.org; San Francisco Chronicle, January 16, 21, 2005; Washington Post, February 18, 2005; Amy Quinn, "What Now for the Peace Movement?" TomPaine.com, March 9, 2005; Los Angeles Times, January 19, 21, 2005; Lincoln County News (Maine), January 27, 2005; New York Times, January 29, 2005.

27. Washington Post, March 20, 2005; New York Times, March 20, 2005; Kauffman interview; Reuters article, March 19, 2005.

28. Washington Post, March 20, 2005; Karen Houppert, "The New Face of Protest?" The Nation, March 28, 2005; Kauffman interview; USA Today, March 17,
2005; Denver Post, March 16, 2005.

29. Washington Post, March 25, 2005; Ann Arbor News, March 25, 2005.

30. Marshall interview; Gerson interview; Cortright interview; Becker interview; Kauffman interview; www. unitedforpeace.org; www.countingthecost.org.

31. Reuters article, October 28, 2004.

32. Alexander Cockburn, "The Antiwar Movement and Its Critics," The Nation, December 2, 2002; Wells, The War Within, pp. 144-145, 211-212, 315-318, 324, and 396 (and elsewhere on draft protests).

33. Phyllis Bennis, "Half a Victory at the UN," The Nation, December 2, 2002; Gerson interview; Cortright interview; AP article, March 16, 2005; New York Times, April 20, 2003; Kauffman interview; Contra Costa Times (California), February 7, 2005.

34. Lawrence Freedman, “The Iraq Syndrome," Washington Post National Weekly Edition, January 1723, 2005. 